\title{
Large-Scale Purification, Characterization, and Spore Outgrowth Inhibitory Effect of Thurincin H, a Bacteriocin Produced by Bacillus thuringiensis SF361
}

\author{
Gaoyan Wang • David C. Manns • Giselle K. Guron • \\ John. J. Churey • Randy W. Worobo
}

Published online: 6 May 2014

(c) Springer Science+Business Media New York 2014

\begin{abstract}
Large-scale purification of the highly hydrophobic bacteriocin thurincin $\mathrm{H}$ was accomplished via a novel and simple two-step method: ammonia sulfate precipitation and C18 solid-phase extraction. The inhibition spectrum and stability of thurincin $\mathrm{H}$ as well as its antagonistic activity against Bacillus cereus F4552 spores were further characterized. In the purification method, secreted proteins contained in the supernatant of a $40 \mathrm{~h}$ incubated culture of $B$. thuringiensis SF361 were precipitated by $68 \%$ ammonia sulfate and purified by reverse-phase chromatography, with a yield of $18.53 \mathrm{mg} / \mathrm{l}$ of pure thurincin H. Silver-stained SDS-PAGE, high-performance liquid chromatography, and liquid chromatography-mass spectrometry confirmed the high purity of the prepared sample. Thurincin $\mathrm{H}$ exhibited a broad antimicrobial activity against 22 tested bacterial strains among six different genera including Bacillus, Carnobacterium, Geobacillus, Enterococcus, Listeria, and Staphylococcus. There was no detectable activity against any of the selected yeast or fungi. The bacteriocin activity was stable for $30 \mathrm{~min}$ at $50{ }^{\circ} \mathrm{C}$ and decreased to undetectable levels within $10 \mathrm{~min}$ at temperatures above $80{ }^{\circ} \mathrm{C}$. Thurincin $\mathrm{H}$ is also stable from $\mathrm{pH} 2-7$ for at least $24 \mathrm{~h}$ at room temperature. Thurincin $\mathrm{H}$ is germicidal against $B$. cereus spores in brain heart infusion broth, but not in Tris- $\mathrm{NaCl}$ buffer. The efficient purification method enables the large-scale
\end{abstract}

G. Wang · D. C. Manns · G. K. Guron ·

John. J. Churey · R. W. Worobo $(\square)$

Food Research Lab, Department of Food Science, College of

Agriculture and Life Sciences, Cornell University, $630 \mathrm{~W}$ North

Street, Geneva, NY 14456, USA

e-mail: rww8@cornell.edu

G. Wang

e-mail: gw236@cornell.edu production of pure thurincin $\mathrm{H}$. The broad inhibitory spectrum of this bacteriocin may be of interest as a potential natural biopreservative in the food industry, particularly in post-processed and ready-to-eat food.

Keywords Bacillus bacteriocin - Antilisterial . Large-scale purification $\cdot$ Stability $\cdot$ Minimum inhibition concentration · Germicidal

\section{Introduction}

Foodborne diseases and spoilage caused by microorganisms have long been a challenge for public health concerns and the food processing industry. It is estimated that 9.4 million illnesses, 55,961 hospitalizations, and 1,351 deaths were caused by 31 major foodborne pathogens each year in the USA (90\% credible interval as estimated by the CDC) [1]. Among the bacteria, yeasts, and molds responsible for general food spoilage and their resulting economic losses, spore-forming bacteria are of particular concerns for the food industry due to their high heat resistance, and higher tolerance to drying, freezing, and chemical disinfectants [2].

Bacteriocins are ribosomally synthesized peptides or proteins produced by bacteria that exhibit antimicrobial activity against other bacteria mostly within the same species (narrow spectrum) or sometimes across different genera (broad spectrum) [3]. Bacteriocins produced by Gram-positive bacteria, most commonly lactic acid bacteria, have been widely applied in the food industry because of their effectiveness against various foodborne pathogens and spoilage microorganisms [4]. Bacillus spp. have gained recent research interest since they are considered rich producers of different types of antibiotics, antimicrobial 
protein or peptides, and antifungal substances [5, 6]. Bacillus spp. strains generally exhibit a broad inhibition spectrum and occasionally inhibit yeasts and molds, even bacterial spores [5]. For example, haloduracin produced by the alkaliphile isolate $B$. halodurans $\mathrm{C}-125$ was reported to inhibit spore outgrowth of B. anthracis [7].

Thurincin $\mathrm{H}$ is a bacteriocin produced by Bacillus thuringiensis SF361, a strain originally isolated from US domestic honey [8]. The producer strain inhibits the growth of several Gram-positive foodborne pathogens and food spoilage microorganisms, such as L. monocytogenes and $B$. cereus, based on overlay assays [8]. The mature thurincin $\mathrm{H}$ is composed of 31 amino acids with a molecular mass of 3,139.51 Da [8]. According to a recent three-dimensional NMR spectroscopy study, the helical backbone of mature thurincin $\mathrm{H}$ folds to form a hairpin structure with backbones stabilized by four sulfur to $\alpha$-carbon bridges [20].

The objective of this study was to develop an efficient and reproducible method to produce and purify large amounts of highly pure thurincin $\mathrm{H}$. Additionally, to further evaluate its potential as a natural preservative, the inhibition spectrum, stability under various conditions as well as its antagonistic activity against Bacillus spores were determined.

\section{Materials and Methods}

\section{Bacterial Strains and Culture Conditions}

The thurincin $\mathrm{H}$ producing strain B. thuringiensis SF361 and the indicator strain $B$. cereus $\mathrm{F} 4552$ were cultivated in trypticase soy broth (TSB) or on trypticase soy agar (TSA) (BD, Sparks, MD) at $37{ }^{\circ} \mathrm{C}$. Yeast and fungi were cultivated in potato dextrose agar (PDA) (Hardy diagnostics, Santa Maria, CA) or potato dextrose broth (PDB) (BD, Sparks, MD) adjusted $\mathrm{pH}$ to 3.5 with a $10 \%$ sterile tartaric acid solution added after autoclaving. Phosphatebuffered saline (PBS) at $\mathrm{pH} 7$ was formulated with $8 \mathrm{~g}$ $\mathrm{NaCl}, 0.2 \mathrm{~g} \mathrm{KCl}, 1.44 \mathrm{~g} \mathrm{Na}_{2} \mathrm{HPO}$, and $0.24 \mathrm{~g} \mathrm{KH}_{2} \mathrm{PO}_{4}$ per liter. In spore germination studies, spores were incubated in brain heart infusion (BHI) broth (BD, Sparks, MD) at $30{ }^{\circ} \mathrm{C}$ for $1 \mathrm{~h}$ with $250 \mathrm{rpm}$ shaking. All chemicals and reagents were either autoclaved at $121{ }^{\circ} \mathrm{C}$ for $15 \mathrm{~min}$ or filtrated by polyethersulfone membrane $(0.22 \mu \mathrm{m})$, prior to use.

\section{B. cereus F4552 Spore Preparation and Quantification}

One single fresh colony of B. cereus $\mathrm{F} 4552$ was inoculated into $5 \mathrm{ml} \mathrm{TSB}$ and was incubated for $5 \mathrm{~h}$ at $37{ }^{\circ} \mathrm{C}$ with shaking at $225 \mathrm{rpm}$. One milliliter of this culture was evenly spread on SPO 8 solid agar plate [9] and incubated at $20{ }^{\circ} \mathrm{C}$ for 7 days. The resulting spores were transferred from the plate surface and resuspended in sterile Milli-Q water (Millipore Corporation, Billerica, MA). The suspension was washed three times in ice-cold sterile Milli-Q water, heat treated at $80{ }^{\circ} \mathrm{C}$ for $10 \mathrm{~min}$, and stored at $-20{ }^{\circ} \mathrm{C}$ until needed. To determine the concentration, spores were serially diluted and plated on TSA plates. Colonies were counted after a $16 \mathrm{~h}$ incubation at $37^{\circ} \mathrm{C}$ and the concentration of spores were calculated. Two independently prepared spore crops were used throughout this study.

\section{Quantification of Bacteriocin Activity}

The bacteriocin activity was determined by a previously described microtiter plate assay method [10], modified for the current study. In brief, using untreated, clear, flat bottom 96-microwell plates (Thermo Scientific, Nunc, Denmark), $50 \mu \mathrm{l}$ of bacteriocin diluted twofold in the appropriate buffer was mixed with $150 \mu \mathrm{l}$ of $1.33 \%(\mathrm{v} / \mathrm{v})$ B. cereus $\mathrm{F} 4552$ overnight culture in TSB in each well and incubated at $37{ }^{\circ} \mathrm{C}$ for $8 \mathrm{~h}$. The final concentration of indicator strain was approximately $10^{5} \mathrm{CFU} / \mathrm{ml}$. The absorbance at $600 \mathrm{~nm}\left(\mathrm{~A}_{600}\right)$ of each well was measured using a Synergy HT Multi-Mode Microplate Reader (BioTek, Winooski, VT). One arbitrary unit (AU) was defined as the amount of bacteriocin in the $50 \mu \mathrm{l}$ sample that caused a $50 \%$ growth inhibition when compared with the control groups.

\section{Total Protein Concentration Measurement}

The concentration of total protein was measured by the Pierce BCA protein assay kit according to the manufacturer's protocol (Thermo scientific, Rockford, IL).

\section{Thurincin H Production and C18 Purification}

B. thuringiensis SF361 was streaked on a TSA plate and incubated at $37^{\circ} \mathrm{C}$ for $14 \mathrm{~h}$. A single colony was inoculated into $5 \mathrm{ml}$ of TSB and incubated at $37{ }^{\circ} \mathrm{C}$ for $12 \mathrm{~h}$ with shaking at $225 \mathrm{rpm}$. A $1.5 \mathrm{ml}$ aliquot of this incubation was added into $150 \mathrm{ml}$ and incubated at $37^{\circ} \mathrm{C}$ for $40 \mathrm{~h}$ with shaking at $225 \mathrm{rpm}$. Pooled supernatants from multiple incubations $(750 \mathrm{ml}$ in total) were collected after centrifugation $\left(13,000 \times g, 4{ }^{\circ} \mathrm{C}, 40 \mathrm{~min}\right)$. The crude protein fraction was precipitated using ammonium sulfate at a final concentration of $68 \%$ saturation. Pelleted precipitates were resuspended in $150 \mathrm{ml}$ of PBS and purified using C18 Sep Pak Plus tC18 Environmental Cartridges (Waters, Milford, MA). To accomplish this, an SPE cartridge was first equilibrated with $20 \mathrm{ml}$ methanol followed by $20 \mathrm{ml}$ 
PBS buffer. After the supernatant samples were loaded on to the cartridge, $20 \mathrm{ml}$ each of increasing concentrations of acetonitrile $(30,35,45,50,100 \%)$ were consecutively applied to the column. The supernatant, crude protein extract, and each eluted fraction from the cartridge were separately collected and analyzed by high-performance liquid chromatography (HPLC) to evaluate purity as described below. Those fractions $(35-50 \%)$ eluted from the SPE cartridge were pooled, vacuum-centrifuged to remove the acetonitrile mobile phase, and resuspended in $60 \mathrm{ml}$ PBS buffer. Three independent preparations were conducted and purification results are summarized in Table 1.

\section{High-Performance Liquid Chromatography (HPLC)}

The purity of thurincin $\mathrm{H}$ preparations was monitored via HPLC using a Jupiter 300 C5 column $(250 \mathrm{~mm} \times$ $4.6 \mathrm{~mm} ; 5 \mu \mathrm{m}$ particle size; $300 \AA$ A pore size; Phenomenex, Torrance, CA) connected to an Agilent series 1100 HPLC system with in-line degasser, quaternary pump, and diode array detector set to monitor at $214 \mathrm{~nm}$ [11]. A $50 \mu \mathrm{l}$ sample was loaded onto the column, and active fractions were resolved using a starting mobile phase of $5 \%$ acetonitrile in water supplemented with $0.1 \%$ trifluoroacetic acid (TFA) and linearly increased to $100 \%$ acetonitrile $(0.1 \%$ TFA) over a $30 \mathrm{~min}$ period at a $1 \mathrm{ml} / \mathrm{min}$ flow rate.

\section{Tricine-SDS-PAGE and Silver Staining}

Thurincin $\mathrm{H}$ preparations were visually monitored on a three-layer tricine gel system consisting of a loading layer (4 \% acrylamide, $30 \%$ solution, 29:1 ratio; Bio-Rad, Hercules, CA), a stacking layer (10\% acrylamide), and a resolving layer (15\% acrylamide supplemented with $9 \%$ glycerol) as previously described [11]. An appropriate amount of each sample and $2 \mu \mathrm{l}$ of Precision Plus Protein Dual Xtra Standards Marker (Bio-Rad) ranging from 2 to $250 \mathrm{kDa}$ were boiled for $5 \mathrm{~min}$ in PAGE buffer [12], rapidly chilled on ice, and loaded onto the gel built on a mini-Protean III gel platform (Bio-Rad, Hercules, CA). After $120 \mathrm{~min}$ at $110 \mathrm{~V}$, gels were thoroughly washed using Milli-Q water and fixed in $5 \%$ glutaraldehyde for $1 \mathrm{~h}$ with gentle shaking. Gels were rinsed multiple times and silver-stained using the recommended standard protocol (Bio-Rad, Hercules, CA).

\section{Liquid Chromatography-Mass Spectrometry (LC-MS)}

LC-MS was performed at the Proteomics and Mass Spectrometry Core Facility Center at Cornell University to determine the accurate molecular mass (Ithaca, NY).

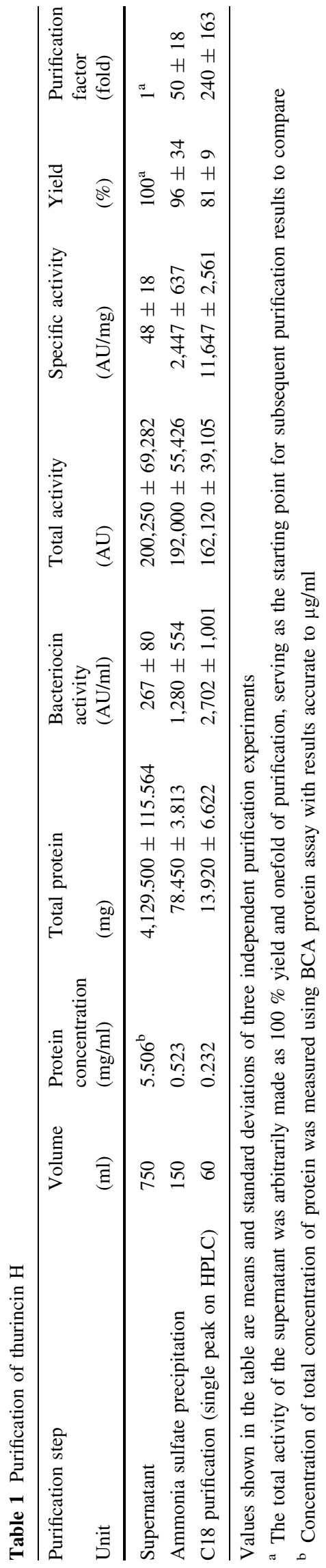


Minimum Inhibitory Concentration (MIC) of Thurincin $\mathrm{H}$ against Different Bacterial Strains

The MICs of thurincin $\mathrm{H}$ against 27 different bacteria were determined by the microtiter plate assay method described earlier. The lowest concentration $(\mu \mathrm{g} / \mathrm{ml})$ of purified thurincin $\mathrm{H}$ that allowed $50 \%$ growth of each strain was determined as the MIC [13]. At least three independent assays were performed for each strain.

Inhibition Against Yeast and Fungi

Inhibition to different yeasts and fungi strains was evaluated via a spot on lawn assay [14]. Fifty microliters of $48 \mathrm{~h}$ cultures of yeast or fungi incubated in PDB was inoculated into $8 \mathrm{ml}$ soft PDA (0.75\% agar) and overlaid on a PDA base plate. Ten microliters of thurincin $\mathrm{H}(500 \mu \mathrm{g} / \mathrm{ml})$ was spotted on top and incubated at $30{ }^{\circ} \mathrm{C}$. The presence/absence of clear inhibition zones were periodically checked within $24-48$ h. At least three assays were conducted for each strain.

Acidic and Basic Stability

Pure thurincin $\mathrm{H}$ resuspended in sterile water was mixed with sterile $\mathrm{pH}$-adjusted TSB (varying integrally from 1 to $12,8.2,8.4,8.6$, and 8.8 ) at a $1: 10$ ratio. The initial bacteriocin activity of diluted thurincin $\mathrm{H}$ in TSB (at $\mathrm{pH} 7$ ) was $320 \mathrm{AU} / \mathrm{ml}$. After a $24 \mathrm{~h}$ incubation at $22^{\circ} \mathrm{C}$, each mixture was neutralized by $\mathrm{HCl}$ or $\mathrm{NaOH}$. Residual activity was measured by microtiter plate method. Three independent experiments were performed.

\section{Thermal Stability}

Thurincin $\mathrm{H}$ (640 AU/ml) in PBS buffer was heated in a water bath at varying temperatures $\left(50,60,70,80,90{ }^{\circ} \mathrm{C}\right)$ for a set time period and immediately cooled on ice after treatment. Residual bacteriocin activity was measured by microtiter plate method as described in "Quantification of bacteriocin activity" section. Three independent experiments were performed.

Inhibitory Effect of Thurincin $\mathrm{H}$ against B. cereus Spores

Fifty microliters of thurincin $\mathrm{H}(500 \mu \mathrm{g} / \mathrm{ml})$ diluted $1: 2$ in Tris- $\mathrm{NaCl}$ buffer (10 mM Tris, $10 \mathrm{mM} \mathrm{NaCl}, \mathrm{pH}$ 7.4) was added to the wells of an untreated, clear, flat bottom 96-microwell plate (Thermo Scientific) and mixed with $150 \mu \mathrm{l}$ of $B$. cereus F4552 spores resuspended in BHI. The final concentrations of spores in the mixture were $10^{4}, 10^{5}$, $10^{6}$, and $10^{7} \mathrm{CFU} / \mathrm{ml}$. Tris- $\mathrm{NaCl}$ buffer served as a control. The plates were incubated at $37^{\circ} \mathrm{C}$ for $8 \mathrm{~h}$. The minimum concentration that caused $50 \%$ inhibition of spore outgrowth was determined. Two independent experiments in triplicates were performed.

\section{Effect of Thurincin H on Spore Hydration}

Absorbance of spore suspension at $600 \mathrm{~nm}\left(\mathrm{~A}_{600}\right)$ decreased as the spore rehydration in the germinating process caused alteration in its light-scattering behavior $[15,16]$. Using a 96-well microtiter plate, a $150 \mu \mathrm{l}$ aliquot of $B$. cereus spores resuspended in $\mathrm{BHI}$ or Tris- $\mathrm{NaCl}$ was combined with $50 \mu$ of purified thurincin $\mathrm{H}$ in Tris- $\mathrm{NaCl}$ buffer to a final concentration of 10 , or $0 \mu \mathrm{g} / \mathrm{ml}$ (control). The final concentration of spores in presence of thurincin $\mathrm{H}$ was approximately $10^{7} \mathrm{CFU} / \mathrm{ml}$. $\mathrm{A}_{600}$ was immediately read for $1 \mathrm{~h}$ at $2 \mathrm{~min}$ intervals. Before each reading, plates were automatically shaken rapidly for $30 \mathrm{~s}$. The result was presented as the percentage of $\mathrm{A}_{600}$ at each time point normalized to the initial point. Two independent experiments were performed in duplicates.

Inhibitory Effect upon Germination

Spores were resuspended in BHI or Tris- $\mathrm{NaCl}$ buffer with or without thurincin $\mathrm{H}$ at a concentration of approximately $10^{7} \mathrm{CFU} / \mathrm{ml}$ and incubated in $30{ }^{\circ} \mathrm{C}$ for $60 \mathrm{~min}$. For the experimental group, the final concentration thurincin $\mathrm{H}$ was $100 \mu \mathrm{g} / \mathrm{ml}$. After $60 \mathrm{~min}$, all samples were immediately serially diluted with $0.1 \%$ peptone water and plated on TSA plate. Two independently prepared spores crops were assayed in quadruplicates.

\section{Statistical Analysis}

For the "Effect of thurincin $\mathrm{H}$ on spore hydration" section experiment, the $\mathrm{A}_{600}$ of all the six groups after the $60 \mathrm{~min}$ of different treatments was compared by a two-way ANOVA. For the "Inhibitory effect upon germination" section experiments, all $\mathrm{CFU} / \mathrm{ml}$ data were first transformed to $\log _{10}(\mathrm{CFU} / \mathrm{ml})$ and divided by control. Those percentages were used for analysis of differences by a twoway ANOVA. The Holm-Sidak method was used to do all pairwise multiple comparison procedures $(p=0.05)$. Statistical analyses were conducted using SigmaPlot 12.0 (Systat Software Inc, San Jose, CA).

\section{Results}

Bacteriocin Production and Purification

Based on a preliminary time-course study between incubation time and bacteriocin activity of cell-free 
supernatant, initial bacteriocin activity was detected after $8 \mathrm{~h}$, reached a stable activity maximum between $36 \mathrm{~h}$ and $46 \mathrm{~h}$, and remained stable for at least $90 \mathrm{~h}$ throughout an incubation time course at $37^{\circ} \mathrm{C}$ (data not shown). For the three independent thurincin $\mathrm{H}$ purification trials, the supernatant was harvested after a $40 \mathrm{~h}$ incubation at $37{ }^{\circ} \mathrm{C}$.

Based on the HPLC analysis of cell-free supernatant in Fig. 1a, most of the compounds residing in the supernatant were eluted prior to thurincin $\mathrm{H}$ (22.1 min). No significant peaks were detected after $22.1 \mathrm{~min}$, indicating the strong hydrophobicity of thurincin $\mathrm{H}$. Following the ammonia sulfate precipitation step, the concentration and purity of thurincin $\mathrm{H}$ were significantly increased and were the dominant peak in the elution profile (Fig. 1b). The strongly hydrophobic nature of thurincin $\mathrm{H}$ was exploited to optimize its large-scale purification using high-capacity C18 cartridges. In the large-scale purification, single HPLC resolved peak resulted from the 35, 45, and $50 \%$ acetonitrile eluates as shown in Fig. 1c. Each step of the purification process was visually assessed via silver-stained SDS-PAGE as the effects of each stage are shown, culminating in the presence of one single band for the final purified thurincin $\mathrm{H}$ (Fig. 1d). For further confirmation of purity and identity, the LC-MS data showed an intact molecular mass of 3,139.52 Da, which is consistent with the previously reported molecular mass of thurincin $\mathrm{H}$ (data not shown) [8]. This new purification method is simple and fast, giving an $81 \%$ bacteriocin activity recovery rate (Table 1 ) in only two steps.

Stability

Similar to many acid-stable yet alkaline-labile class I and class II bacteriocins from lactic acid bacteria [17], thurincin $\mathrm{H}$ was stable from $\mathrm{pH} 2-7$ up to at least $24 \mathrm{~h}$ at room temperature. Bacteriocin activity was partially lost in slightly basic solutions and completely lost at $\mathrm{pH} 9-11$ within $24 \mathrm{~h}$ at room temperature, as shown in Fig. $2 \mathrm{a}$. When thurincin $\mathrm{H}$ was exposed to increased temperatures in PBS buffer, the bacteriocin activity remained for $30 \mathrm{~min}$ at $50{ }^{\circ} \mathrm{C}$ but half of the activity dropped at $50{ }^{\circ} \mathrm{C}$ by $60 \mathrm{~min}$, at $60^{\circ} \mathrm{C}$ by $10 \mathrm{~min}$, and at $70^{\circ} \mathrm{C}$ in less than $10 \mathrm{~min}$. Thurincin $\mathrm{H}$ lost most of its activity within $3 \mathrm{~min}$ at temperatures above $80^{\circ} \mathrm{C}$, as in Fig. 2 b.

\section{Inhibition Spectrum and MICs}

Thurincin $\mathrm{H}$ exhibited a wide antimicrobial spectrum against one or more species across several genera including Bacillus, Listeria, Carnobacterium, Enterococcus, Staphylococcus, and Geobacillus. Among all the 22 sensitive strains, 14 of them are spore formers in or close to the Bacillus genus. The MICs are strain dependent, ranging from 0.28 to $21.9 \mathrm{nM}$ for Gram-positive strains. None of
Fig. 1 Purification of thurincin H. a HPLC of $40 \mathrm{~h}$ supernatant. b HPLC of semi-purified thurincin $\mathrm{H}$ after ammonium sulfate precipitation. c Thurincin $\mathrm{H}$ after $\mathrm{C} 18$ purification. d SDS-PAGE and silver staining. Lane 1 Bio-Rad Precision Plus Protein ${ }^{\mathrm{TM}}$ Dual Xtra Standards, lane 2 supernatant, lane 3 semipurified thurincin $\mathrm{H}$ after ammonium sulfate precipitation, lane 4 thurincin $\mathrm{H}$ after $\mathrm{C} 18$ purification (a)

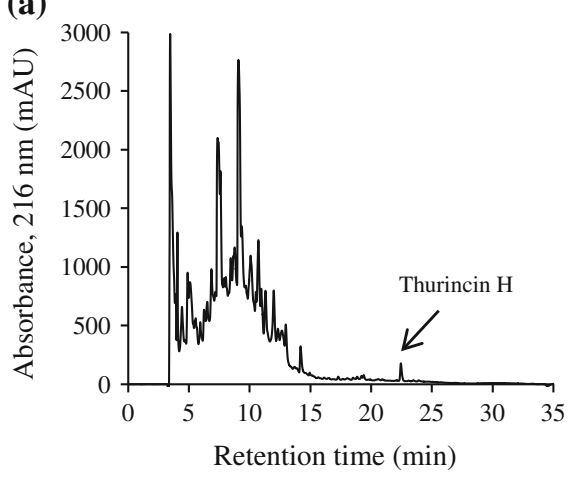

(c)

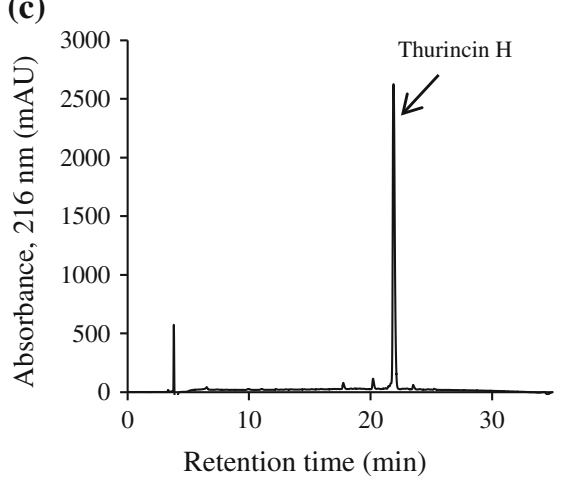

(b)

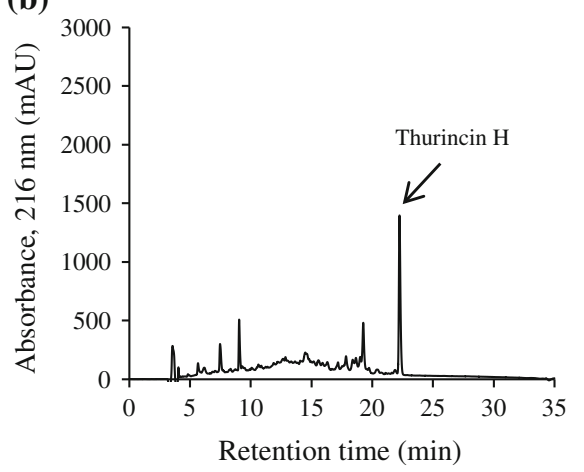

(d)

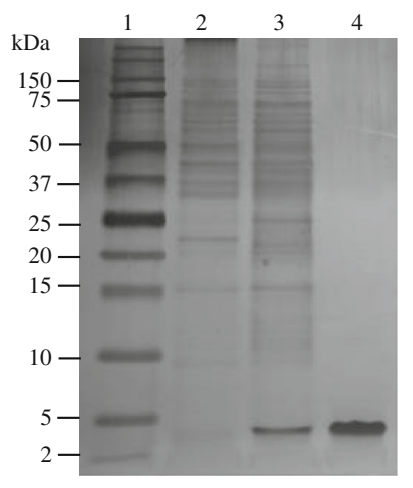



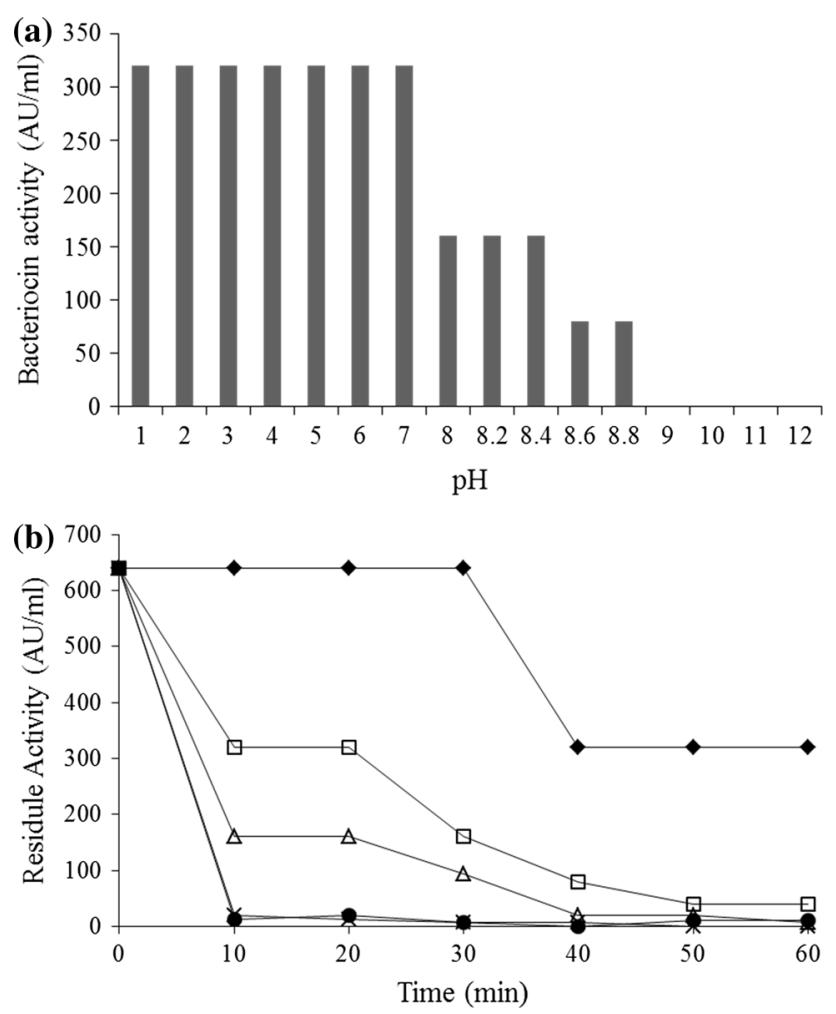

Fig. 2 Stability of thurincin $\mathrm{H}$. a Thurincin $\mathrm{H}$ was stable under acidic conditions for $24 \mathrm{~h}$, but gradually lost activity under alkaline conditions. b Thurincin $\mathrm{H}$ was heat labile. The data in shown in the figure are means of multiple independent experiments, and there was no discernible deviation in the microtiter bacteriocin activity assays for all the samples measured. Solid line with diamond $50{ }^{\circ} \mathrm{C}$, solid line with square $60{ }^{\circ} \mathrm{C}$, solid line with triangle $70{ }^{\circ} \mathrm{C}$, solid line with circle $80{ }^{\circ} \mathrm{C}$, solid line with star $90{ }^{\circ} \mathrm{C}$

the three Gram-negative bacteria were inhibited by thurincin $\mathrm{H}$, as shown in Table 2 .

Thurincin $\mathrm{H}$ is ineffective against any of the nine selected yeast strains (Candida albicans 3153A, Dekkera anomala, Geotrichum candidum 755, Pichia stipitis CBS 6054, Rhodotorula mucilaginosa, Saccharomyces bisporus, Saccharomyces cerevisiae, Zygosaccharomyces baillii, and Zygosaccharomyces bisporus) or the ten mold strains (Aspergillus flavus, Aspergillus niger 2270, Byssochlamys fulva G-1, Byssochlamys fulva H25, Neosartorya fischeri, Penicillium expansum 7861, Penicillium vermiculation, Rhizopus oligosporus, Rhizopus oryzae, and Talaromyces flavus).

\section{Effect of Thurincin $\mathrm{H}$ on Bacillus Spores}

The MICs of thurincin $\mathrm{H}$ against $B$. cereus $\mathrm{F} 4552$ spores were $3.8 \mu \mathrm{g} / \mathrm{ml}$ for $10^{4} \mathrm{CFU} / \mathrm{ml}$ and $7.6 \mu \mathrm{g} / \mathrm{ml}$ for $10^{5}$ $10^{7} \mathrm{CFU} / \mathrm{ml}$ at $30^{\circ} \mathrm{C}$ in $\mathrm{BHI}$ for $12 \mathrm{~h}$. At the same incubation medium and temperature, no optical density increase in B. cereus was observed at the concentration of equal to or higher than 2 times of MIC for up to 1 week. After incubating thurincin $\mathrm{H}$ with spores for 1 week at $30{ }^{\circ} \mathrm{C}$, the suspension was centrifuged and plated out on $\mathrm{BHI}$ agar plate and no colonies were formed on the plates (data not shown).

In studying its bacterial germicidal mechanism, as shown in Fig. 3a, when spores were resuspended in Tris$\mathrm{NaCl}$ buffers (restricting germination), the $\mathrm{A}_{600}$ remained stable with or without the presence of thurincin $\mathrm{H}$. When spores were resuspended in a nutrient-rich $\mathrm{BHI}$ broth (encouraging germination), the decrease in $\mathrm{A}_{600}$ showed no significant difference in the presence or absence of thurincin $\mathrm{H}(p>0.05)$.

To determine whether thurincin $\mathrm{H}$ kills spores before spore germination initiation, thurincin $\mathrm{H}$ was mixed with $B$. cereus spores in Tris- $\mathrm{NaCl}$ buffers or BHI nutrient broth. The results showed that thurincin $\mathrm{H}$ caused significant decrease in viable counts only in the condition that germination was induced by BHI $(p<0.05)$. There were no significant viable count changes when spores was resuspended in Tris- $\mathrm{NaCl}$ buffer in presence of thurincin $\mathrm{H}$ $(p>0.05)$, as shown in Fig. $3 b$.

\section{Discussion}

An effective thurincin $\mathrm{H}$ production and purification method was developed. In the bacteriocin production, rich TSB medium was used to provide enough nutrients for the producer B. thuringiensis SF361 to grow robustly and reach high cell density. The bacteriocin activity curve is consistent with previous reports indicating the production of bacteriocins are triggered under conditions of high stress, such as overpopulation and nutrient limitation during early stationary phase $[18,19]$. In devising a scaled-up purification method, the hydrophobic nature of thurincin $\mathrm{H}$ was critical. The amino acid sequence showed that thurincin $\mathrm{H}$ is overall negatively charged, while the 3-D structure elucidated by NMR demonstrated that the uncharged residues form a hydrophobic region on one side of the hairpin loop structure [20]. This unique feature formed theoretical basis for $\mathrm{C} 18$ solid-phase extraction method as thurincin $\mathrm{H}$ binds to the $\mathrm{C} 18$ column more tightly than most of the substances in the supernatant shown in Fig. 1a. Thurincin $\mathrm{H}$ was previously purified in small quantities using hydrophobic octyl-Sepharose CL-4B cartridge (GE Healthcare, Piscataway, NJ). Subsequent to a crude ammonia sulfate precipitation and application to the cartridge, thurincin $\mathrm{H}$ was eluted by a continuously decreasing gradient of ammonia sulfate followed by an increasing gradient of ethanol in water [8]. This laborious purification method is not feasible to purify large quantities of pure thurincin $\mathrm{H}$, since the thurincin $\mathrm{H}$ peak overlaps 
Table 2 MICs of thurincin $\mathrm{H}$ against different bacteria

\begin{tabular}{|c|c|c|c|c|c|}
\hline \multirow[t]{2}{*}{ Strains } & \multirow[t]{2}{*}{ Medium } & \multirow[t]{2}{*}{ Incubation (h) } & \multirow[t]{2}{*}{ Temp $\left({ }^{\circ} \mathrm{C}\right)$} & \multicolumn{2}{|l|}{ MIC } \\
\hline & & & & $\begin{array}{l}(\mu \mathrm{g} / \\
\mathrm{ml})\end{array}$ & $(\mathrm{nM})$ \\
\hline Bacillus cereus $\mathrm{F} 4552$ & TSB & 12 & 37 & 1.70 & 0.54 \\
\hline Bacillus cereus $\mathrm{F} 4810$ & TSB & 12 & 37 & 1.70 & 0.54 \\
\hline Bacillus cereus Northland & TSB & 12 & 37 & 4.70 & 1.50 \\
\hline Bacillus cereus Northview P2E018 & TSB & 12 & 37 & 7.05 & 2.25 \\
\hline Bacillus licheniformis & TSB & 12 & 37 & 68.75 & 21.90 \\
\hline Bacillus megaterium LRB89 & TSB & 17 & 37 & 0.44 & 0.14 \\
\hline Bacillus subtilis ATCC 6537 & TSB & 14 & 37 & 4.60 & 1.47 \\
\hline Bacillus subtilis CU1065(WT) & TSB & 17 & 37 & 36.94 & 11.77 \\
\hline Bacillus subtilis LRB90 & TSB & 14 & 37 & 9.23 & 2.94 \\
\hline Bacillus subtilis LRB91 & TSB & 14 & 37 & 2.31 & 0.73 \\
\hline Bacillus subtilis ATCC 6633 & TSB & 14 & 37 & 1.15 & 0.37 \\
\hline Bacillus thuringiensis SF361 & TSB & 12 & 37 & 18.44 & 5.87 \\
\hline Bacillus thuringiensis EG10368 & TSB & 12 & 37 & 0.85 & 0.27 \\
\hline Carnobacterium piscicola CU216 & APT & 12 & 30 & 0.88 & 0.28 \\
\hline Enterobacter agglomerans $\mathrm{J}-1$ & TSB & 12 & 37 & $-{ }^{\mathrm{a}}$ & - \\
\hline Enterococcus mundtii EM & TSB & 12 & 37 & 68.75 & 21.90 \\
\hline Geobacillus stearothermophilus ATCC 12980 & TSB & 24 & 50 & 0.88 & 0.28 \\
\hline Listeria inпосиа АТСС 2283 & TSB & 17 & 37 & 0.88 & 0.28 \\
\hline Listeria ivanovii ATCC 19119 & TSB & 12 & 37 & 0.88 & 0.28 \\
\hline Listeria monocytogenes F2 5861053 & TSB & 17 & 37 & 1.76 & 0.56 \\
\hline Listeria monocytogenes 2289 & TSB & 17 & 37 & 1.76 & 0.56 \\
\hline Paenibacillus larvae subsp larvae ATCC 25747 & TSB & 12 & 37 & - & - \\
\hline Pseudomona syringae pv. papulans 51 & TSB & 12 & 37 & - & - \\
\hline Staphylococcus aureus ATCC 9144 & TSB & 14 & 37 & 36.94 & 11.77 \\
\hline Staphylococcus aureus ATCC 8095 & TSB & 14 & 37 & 18.44 & 5.87 \\
\hline Streptococcus faecalis ATCC 8043 & TSB & 12 & 37 & - & - \\
\hline Vibrio parahaemolyticus G1-166 (03:k6) & TSB & 12 & 37 & - & - \\
\hline
\end{tabular}

There was no discernible deviation in the assay of the MICs for all samples measured

a The growth of the strain was not inhibited by the applied thurincin $\mathrm{H}$ in the experiment with neighboring contaminating peaks lead to a decreased yield as shown by the chromatography results. Furthermore, hundreds of samples had to be collected in order to simply identify the target thurincin $\mathrm{H}$. This novel C18 purification cartridge and the columns in HPLC both used carbon chain-based hydrophobic stationary phase as well as a similar composition for the mobile phase/eluent. A range of $35-50 \%$ acetonitrile was sufficient to elute the pure thurincin $\mathrm{H}$ from the cartridge, greatly increasing the reproducibility of the method compared with using a gradient-based mobile cleanup and elution scheme. This purification method is far superior than most purification methods, since usually more than two purification steps were applied during the entire purification process, resulting is cumulative losses at each step.

Compared with thurincin $\mathrm{H}$, some bacteriocins from lactic acid bacteria could remain stable after extreme heat treatments (e.g., plantaricin LP84, $20 \mathrm{~min}$ at $121{ }^{\circ} \mathrm{C}$ ) [21]. Samples treated at $100{ }^{\circ} \mathrm{C}$ for $10 \mathrm{~min}$ and at $\mathrm{pH} 10$ for $12 \mathrm{~h}$ (and subsequently neutralized) were analyzed via HPLC and LC-MS. The peak representing the intact thurincin $\mathrm{H}$ at 22.1 min completely disappeared and several novel, yet earlier eluting peaks dominated the HPLC spectra (data not shown). Furthermore, an intact molecular mass for thurincin $\mathrm{H}$ was not detected in the heat- or alkaline-processed samples via LC-MS. These results indicated that the loss of activity was not simply due to a conformational change, but chemical degradation. The peptide backbone of thurincin $\mathrm{H}$ after thermal and basic condition treatment might be degraded.

Purified thurincin $\mathrm{H}$ showed a broad inhibition spectrum against bacteria, unlike those bacteriocins produced by lactic acid bacteria mostly inhibiting closely related species [22]. A highly purified bacteriocin is required to verify the activity of the specific bacteriocin under review, as more than one antimicrobial compounds are often produced by the same strain. For instance, Bacillus subtilis JM4 was reported to produce two antimicrobial peptides that 

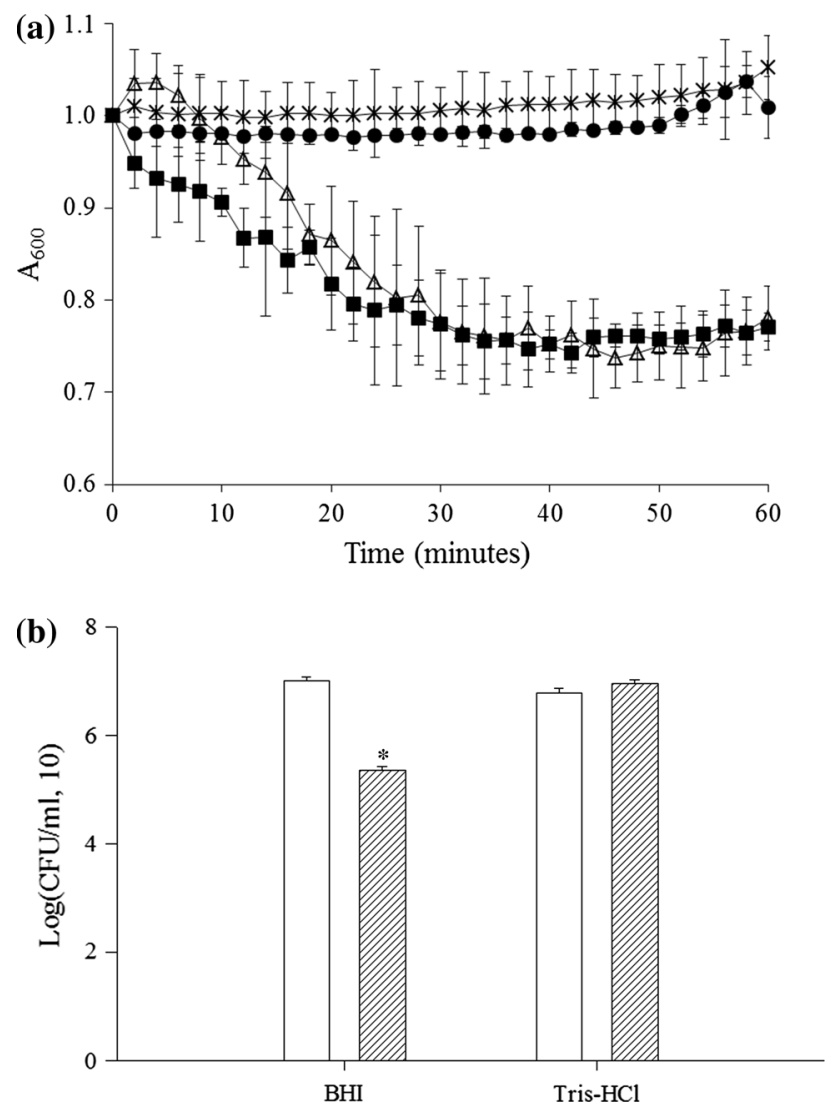

Fig. 3 Inhibitory effect of thurincin $\mathrm{H}$ against Bacillus spores. a Thurincin $\mathrm{H}$ did not prevent Bacillus spore germination initiation in $\mathrm{BHI}$ or induce Bacillus spore germination initiation in Tris- $\mathrm{NaCl}$ buffer. Solid line with square BHI (thurincin $\mathrm{H} 10 \mu \mathrm{g} / \mathrm{ml}$ ), solid line with triangle $\mathrm{BHI}$ control, solid line with star Tris-NaCl buffer (thurincin $\mathrm{H} 10 \mu \mathrm{g} / \mathrm{ml}$ ), solid line with circle Tris-NaCl buffer control. b Germination is required for the action of thurincin $\mathrm{H}$. Mean and error bars of multiple experiments are shown in the figure. Square bar thurincin $\mathrm{H}(0 \mu \mathrm{g} / \mathrm{ml})$, stripped bar thurincin $\mathrm{H}(100 \mu \mathrm{g} /$ $\mathrm{ml})$. Asterisk significant viable count decrease $(p<0.05)$

differed by only one amino acid, subpeptin JM4-A and subpeptin JM4-B [23]. Thurincin H did not show inhibitory effect against selected yeast or fungi in our study. Several Bacillus strains were reported to inhibit growth of yeast and mold, but such studies only tested either the crude supernatant or a partially purified solution of bacteriocin [5]. The substance that inhibits the yeast or mold cannot be traced specifically to the bacteriocin in questions and any inhibitory effects may be due to other substances in solution. For example, the thurincin $\mathrm{H}$ producer $B$. thuringiensis SF361 also produces a $13.484 \mathrm{kDa}$ antifungal protein, $\mathrm{YvgO}$, which inhibits a wide variety of filamentous fungi ranging across several genera, including Aspergillus, Penicillium, and Byssochlamys [11]. To determine whether thurincin $\mathrm{H}$ could induce or block spore germination, the $\mathrm{A}_{600}$ of spores incubated in the presence of thurincin $\mathrm{H}$ was measured [24]. These results indicate that thurincin $\mathrm{H}$ could neither induce nor block spore germination initiation in nutrient-sufficient conditions. This indicates that germination is a prerequisite for the bacterial sporicidal action of thurincin $\mathrm{H}$.

This novel large-scale production and purification system was essential for providing adequate purified materials for other downstream research, such as biochemical characteristics, mode of action, toxicity research or challenge studies in food matrix. The characterization studies in this research indicated the promising potential of thurincin $\mathrm{H}$ to be used as natural food preservatives to protect the food systems.

Acknowledgments This research was supported by USDACSREES (Project \# 2008-51110-0688).

Conflict of interest The authors declare no conflict of interest.

\section{References}

1. Scallan E, Griffin PM, Angulo FJ, Tauxe RV, Hoekstra RM (2011) Foodborne illness acquired in the United States-major pathogens. Emerg Infect Dis 17(1):7-15

2. Nicholson WL, Munakata N, Horneck G, Melosh HJ, Setlow P (2000) Resistance of Bacillus endospores to extreme terrestrial and extraterrestrial environments. Microbiol Mol Biol Rev 64(3):548-572

3. Cotter PD, Hill C, Ross RP (2005) Bacteriocins: developing innate immunity for food. Nat Rev Microbiol 3(10):777-788

4. Settanni L, Corsetti A (2008) Application of bacteriocins in vegetable food biopreservation. Int J Food Microbiol 121(2): 123-138

5. Abriouel H, Franz CM, Ben Omar N, Galvez A (2011) Diversity and applications of Bacillus bacteriocins. FEMS Microbiol Rev 35(1):201-232

6. Stein T (2005) Bacillus subtilis antibiotics: structures, syntheses and specific functions. Mol Microbiol 56(4):845-857

7. Oman TJ, van der Donk WA (2009) Insights into the mode of action of the two-peptide lantibiotic haloduracin. ACS Chem Biol 4(10):865-874

8. Lee H, Churey JJ, Worobo RW (2009) Biosynthesis and transcriptional analysis of thurincin $\mathrm{H}$, a tandem repeated bacteriocin genetic locus, produced by Bacillus thuringiensis SF361. FEMS Microbiol Lett 299(2):205-213

9. Pol IE, van Arendonk WG, Mastwijk HC, Krommer J, Smid EJ, Moezelaar R (2001) Sensitivities of germinating spores and carvacrol-adapted vegetative cells and spores of Bacillus cereus to nisin and pulsed-electric-field treatment. Appl Environ Microbiol 67(4):1693-1699

10. Daba H, Pandian S, Gosselin JF, Simard RE, Huang J, Lacroix C (1991) Detection and activity of a bacteriocin produced by Leuconostoc mesenteroides. Appl Environ Microbiol 57(12):3450-3455

11. Manns DC, Churey JJ, Worobo RW (2012) Functional assignment of $\mathrm{YvgO}$, a novel set of purified and chemically characterized proteinaceous antifungal variants produced by Bacillus thuringiensis SF361. Appl Environ Microbiol 78(8):2543-2552

12. Schägger H (2006) Tricine-SDS-PAGE. Nat Protoc 1(1):16-22

13. Eijsink VG, Skeie M, Middelhoven PH, Brurberg MB, Nes IF (1998) Comparative studies of class IIa bacteriocins of lactic acid bacteria. Appl Environ Microbiol 64(9):3275-3281 
14. Fujita K, Ichimasa S, Zendo T, Koga S, Yoneyama F, Nakayama J, Sonomoto K (2007) Structural analysis and characterization of lacticin Q, a novel bacteriocin belonging to a new family of unmodified bacteriocins of gram-positive bacteria. Appl Environ Microbiol 73(9):2871-2877

15. Hornstra LM, de Vries YP, de Vos WM, Abee T, Wells-Bennik MH (2005) gerR, a novel ger operon involved in L-alanine- and inosine-initiated germination of Bacillus cereus ATCC 14579. Appl Environ Microbiol 71(2):774-781

16. Moir A, Smith DA (1990) The genetics of bacterial spore germination. Annu Rev Microbiol 44:531-553

17. Chen H, Hoover DG (2003) Bacteriocins and their food applications. Compr Rev Food Sci Food Saf 2(3):82-100

18. Riley MA, Gordon DM (1999) The ecological role of bacteriocins in bacterial competition. Trends Microbiol 7(3):129-133

19. Singh J, Banerjee N (2008) Transcriptional analysis and functional characterization of a gene pair encoding iron-regulated xenocin and immunity proteins of Xenorhabdus nematophila. J Bacteriol 190(11):3877-3885
20. Sit CS, van Belkum MJ, McKay RT, Worobo RW, Vederas JC (2011) The 3D solution structure of thurincin $\mathrm{H}$, a bacteriocin with four sulfur to alpha-carbon crosslinks. Angew Chem Int Ed Engl 50(37):8718-8721

21. Suma K, Misra MC, Varadaraj MC (1998) Plantaricin LP84, a broad spectrum heat-stable bacteriocin of Lactobacillus plantarum NCIM 2084 produced in a simple glucose broth medium. Int J Food Microbiol 40(1-2):17-25

22. Drider D, Fimland G, Hechard Y, McMullen LM, Prevost H (2006) The continuing story of class IIa bacteriocins. Microbiol Mol Biol Rev 70(2):564-582

23. Wu S, Jia S, Sun D, Chen M, Chen X, Zhong J, Huan L (2005) Purification and characterization of two novel antimicrobial peptides subpeptin JM4-A and subpeptin JM4-B produced by Bacillus subtilis JM4. Curr Microbiol 51(5):292-296

24. Stewart GS, Johnstone K, Hagelberg E, Ellar DJ (1981) Commitment of bacterial spores to germinate. A measure of the trigger reaction. Biochem J 198(1):101-106 